\title{
Pendampingan Penilaian Autentik Berbasis Karakter untuk Guru Sekolah Dasar
}

\section{Accompaniment of Authentic Based Assessment Characters for Elementary Teachers}

\author{
Deny Setiawan, Apiek Gandamana, Nurhairani \& Reh Bungana Beru PA \\ Universitas Negeri Medan, Indonesia
}

Diterima: 18 Desember 2019 ; Disetujui: 05 Maret 2020 ; Dipublish: 09 Maret 2020

*Corresponding Email : denysetiawan@gmail.com

\section{Abstrak}

Kegiatan pengabdian kepada masyarakat secara umum bertujuaan untuk pembentukan karakter dalam mengembangkan potensi peserta didik yang memiliki kecerdasan, kepribdian dan akhlak mulia. Melalui kegiatan ini untuk mendampingi guru-guru di SD Negeri 104202 Bandar Setia Kecamatan Percut Sei Tuan Kabupaten Deli Serdang dalam pelaksanaan penilaian autentik berbasis karakter. Model yang diterapkan dalam pelaksanaan Pengabdian Kepada masyarakat dilakukan beberapa tahapan yaitu: Pertama, tahap persiapan dengan kegiatan, (a) melakukan sosialisasi kepada guru-guru; (b) melaksanakan observasi dan wawancara; (c) penentuan jadwal kegiatan; dan (d) mempersiapkan sarana dan prasarana. Kedua, Tahap pelaksanaan melalui, (a) Fokus Group Discussion (FGD); (b) pelatihan dan pendidikan penyusunan instrumen penilaian autentik; dan (c) pendampingan penerapan penilaian autentik berbasis karakter. Ketiga, Tahap evaluasi dan refleksi dilakukan adalah penilaian sikap, keterampilan dan pengetahuan. Melalui kegiatan ini guru mempunyai pedoman penilaian autentik berbasis karakter dan terbentuknya Kelompok Kerja Guru (KKG)

Kata Kunci: Penilaian Autentik, Karakter, Guru Sekolah Dasar

\begin{abstract}
Community service activities generally aim to develop character in developing the potential of students who have intelligence, personality and noble character. Through this activity to assist teachers in 104202 Bandar Setia Elementary School, Percut Sei District, Deli Serdang District in carrying out character-based authentic assessments. The model applied in the implementation of Community Service is carried out in several stages, namely: First, the stage of preparation with activities, (a) conducting socialization to teachers; (b) carrying out observations and interviews; (c) determining the schedule of activities; and (d) preparing facilities and infrastructure. Second, the implementation phase through, (a) Focus Group Discussion (FGD); (b) training and education for the preparation of authentic assessment instruments; and (c) assisting in the application of character-based authentic assessments. Third, the evaluation and reflection phase is an assessment of attitudes, skills and knowledge. Through this activity the teacher has character-based authentic assessment guidelines and the formation of the Teacher Working Group (KKG)

Keywords: Authentic Assessment, Character, Elementary School Teacher
\end{abstract}

How to Cite: Setiawan D, Gandamana A, Nurhairani, \& Beru, R.B (2020). Pendampingan Penilaian Autentik Berbasis Karakter untuk Guru Sekolah Dasar. Pelita Masyarakat: Jurnal Pengabdian Masyarakat 1(2) :91-96.

\section{PENDAHULUAN}

Penanaman karakter pada anak usia sekolah dasar dewasa ini sangat diperlukan karena negara Indonesia sedang mengalami krisis karakter dalam diri anak bangsa. Karakter sebagai kepribadian seseorang terbentuk dari hasil internalisasi berbagai 
kebajikan yang diyakini dan digunakan sebagai landasan untuk cara pandang, berpikir, bersikap, dan bertindak. Kebijakan tersebut berupa sejumlah nilai moral, dan norma, seperti jujur, berani bertindak, dapat dipercaya, hormat pada orang lain, disiplin, mandiri, kerja keras, kreatif.

Pembentukan karakter merupakan salah satu tujuan pendidikan nasional. Pasal 1 Undang-Undang Sisdiknas Tahun 2003 menyatakan bahwa di antara tujuan pendidikan nasional adalah mengembangkan potensi peserta didik untuk memiliki kecerdasan, kepribadian dan akhlak mulia. Pentingnya pembentukan karakter pada anak usia sekolah dasar tentunya perlu didukung oleh perangkat pembelajaran yang dapat mendukung penguatan karakter siswa.

Salah satu perangkat pembelajaran tersebut adalah penilaian autentik (authentic assessment) yang berorientasi pada karakter (Damanik \& Setiawan, 2016; Setiawan, 2017; Najmina, 2018; Mustika, \& Sahudra, 2018; Hariyani, 2018). Untuk mencapai nilai karakter, selain dilakukan secara tidak langsung melalui berbagai aktivitas pembelajaran yang dilakukan, guru diharapkan dapat melakukan penilaian secara langsung atas ketercapaian nilai karakter tertentu pada diri siswa (Majid, 2014).

Namun fakta di lapangan, belum semua guru memahami konsep dan pelaksanaan penilaian autentik yang berorientasi pada karakter. Hal ini diungkapkan oleh Rusilowati (Okezone.com, 2013) dalam survei yang dilakukan terhadap 20 dari 23 guru SMP 21 Semarang. Dari jumlah tersebut, 87\% guru ternyata masih kesulitan dalam melakukan penilaian autentik. dari 23 responden sebanyak 87\% mengalami kesulitan dalam memahami cara penilaian, dan 70\% kesulitan dalam pembuatan instrumen observasi.

Data di atas didukung hasil observasi awal pada Sekolah Dasar di Kota Medan, ditemui hampir semua guru kesulitan dalam melakukan penilaian. Hal ini karena banyak guru belum mengerti mengenai penilaian autentik khususnya dalam menilai ketercapaian karakter siswa. Dari 5 sekolah dasar di kota Medan yang telah diobservasi, semuanya menyatakan kesulitan dalam melaksanakan penilaian autentik dalam mengukur ketercapaian nilai karakter tertentu pada siswa. (Setiawan dan Hadikusuma, 2015).

Berdasarkan latar belakang masalah di atas, permasalahan khusus dalam pengabdian ini dijabarkan sebagai berikut:

1. Instrumen penilaian autentik yang ada di sekolah tidak membina karakter yang terarah. 
2. Instrumen penilaian autentik yang ada di sekolah belum telaksana dan belum mencakup ranah pengetahuan, keterampilan dan sikap.

3. Masih banyak guru yang belum melaksanakan penilaian autentik berbasis karakter dalam mengukur ketercapaian nilai karakter tertentu pada diri siswa.

Penilaian autentik berbasis karakter menjadi penting seiring dengan krisis karakter yang saat ini tengah terjadi dalam kehidupan masyarakat Indonesia. Kondisi ini sangat memperihatikan sekaligus menjadi aib bagi pendidikan di Indonesia. Berbagai kondisi sikap mental negatif di atas, merupakan problem bagi pendidikan di Indonesia dan menjadi sebuah persoalan nation and character building. Banyak kalangan mengacungkan telunjuk kepada pendidikan sebagai salah satu penyebab terbesar bagi gagalnya pembentukan insan yang cerdas dan berkarakter (Damanik, 2014; Setiawan, 2014; Dharma \& Siregar, 2014; Rumapea, 2015; Nasution, 2016). Berbagai tokoh di Indonesia mulai peduli terhadap pendidikan dan mencari solusi dalam meningkatkan karakter anak bangsa. Untuk itu, perlu dibangun pendidikan sebagai wahana sistemik pembangunan karakter bangsa secara berkelanjutan.

Berdasarkan permasalahan di atas, salah satu upaya dalam meningkatkan karakter anak bangsa, maka dalam pendidikan di sekolah dasar diperlukan instrumen penilaian autentik berbasis karakter di sekolah dasar yang mencakup ranah kognitif, afektif dan psikomotorik secara komprehensif. Instrumen penilaian autentik berbasis karakter sebagai produk yang dihasilkan dalam pengabdian ini diharapkan dapat membantu guru dalam mengembangkan nilai-nilai karakter pada siswa sekolah dasar dan mengukur ranah kognitif, afektif dan psikomotorik siswa secara terpadu atau komprehensif.

Berdasarkan permasalahan khusus di atas, permasalahan prioritas adalah sebagaimana berikut ini:

1. Belum tersedianya Instrumen penilaian autentik berbasis karakter.

2. Belum memahami konsep penilaian autentik dengan benar.

3. Belum menerapkan penilaian autentik secara utuh yang meliputi ranah : pengetahuan, keterampilan dan sikap.

Solusi untuk mengatasi permasalahan yang ada di atas, solusi untuk mengatasi permasalahan mitra, dapat dilakukan beberapa kegiatan yaitu elatihan dan penyusunan instrumen penilaian autentik, dan sosialisasi pengetahuan tentang konsep penilaian autentik berbasis karakter, serta pendampingan penerapan penilaian autentik berbasis karakter. 


\section{METODE PELAKSANAAN}

Berikut metode yang diterapkan dalam kegiatan pengabdian kepada masyarakat ini, antara lain: FGD, sosialisasi, pelatihan, pendampingan, pendidikan, wawancara, catatan lapangan, observasi, dan kerjasama. Setiap model diaplikasikan berdasarkan tujuan kegiatan yang ingin dicapai. Metode pelaksanaan kegiatan dalam dilaksanakan dalam beberapa tahapan:

\section{a. Persiapan}

Pada tahap ini dilakukan koordinasi dengan Lembaga Pengabdian kepada Masyarakat (LPM) Unimed, persiapan ini melakukan beberapa kegiatan sebagai berikut: (1) sosialisasi program pengabdian kepada mitra di Desa Bandar Setia Kecamatan Perut Sei Tuan Kabupaten Deli Serdang, (2) melaksanakan observasi dan mewawancarai mitra serta melakukan diskusi untuk pemecahan masalah yang ada, (3) penentuan jadwal kegiatan, (4) saling berkomitmen pengabdi dengan mitra, kesiapan peserta untuk mengikuti kegiatan pendampingan penilaian autentik berbasis karakter untuk siswa guru SD dan (5) mempersiapkan sarana dan prasarana untuk mendukung terlaksananya kegiatan pengabdian kepada masyarakat, tempat pelaksanaan kegiatan.

\section{b. Pelaksanaan}

Berikut tahapan pelaksanaan yang dilakukan untuk kegiatan Pengabdian kepada Masyarakat dengan Mitra, yaitu: (1) FDG dengan mitra, (2) pelatihan penyusunan instrument penilaian autentik, pada tahap ini dilakukan perancangan perangkat yang akan dikembangkan, meliputi: (a) penulisan KI, KD dan indikator, dan (b) penulisan instrumen yang akan dikembangkan. Instrumen yang dikebangkan adalah instrument penilaian autentik yang mencakup tiga ranah kompetensi, yakni sikap, keterampilan, dan pengetahuan, (c) sosialisasi

pengetahuan tentang konsep penilaian autentik berbasis karakter, (d) pendampingan penerapan penilaian autentik berbasis karakter. Sosialisasi dan penerapan pendampingan penilaian autentik.

Akhir dari kegiatan ini menghasilkan produk (a) instrumen penilaian autentik berbasis karakter untuk anak SD, dan (b) pedoman penilaian autentik berbasis karakter SD serta (c) KKG/Kelompok Kerja Guru yang melaksanakan penerapan Penilaian Autentik.

\section{c. Evaluasi dan Refleksi}

Evaluasi dan refleksi pengembangan penilaian autentik dilakukan untuk melengkapi penilaian yang belum ada pada buku guru maupun buku siswa karena 
evaluasi belum disusun secara konprehensif untuk ketiga ranah dalam satu kali pembelajaran. Pengembangan instrument penilaian autentik hanya dilakukan pada seluruh tema yang terdapat di kelas sekolah dasar. Pengembangan instrument penilaian ini bukan hanya menggunakan penilaian observasi, tetapi juga berbagai jenis penilaian, yaitu: penilaian sikap (observasi, penilaian diri, penilaian sejawat), keterampilan (unjuk kerja, proyek dan portofolio) dan pengetahuan (ujian tertulis). Beberapa jenis penilaian tersebut merujuk pada Kurikulum 2013.

\section{HASIL DAN PEMBAHASAN}

Dalam menyelesaikan permasalahan di atas, maka pakar dari Unimed adalah Ahli Pendidikan Ilmu Sosial. Pendampingan penilaian autentik berbasis karakter untuk guru SD Desa Bandar Setia Kecamatan Percut Sei Tuan Kabupaten Deli Serdang perlu adanya pelatihan dan pendampingan pembuatan pedoman penilaian autentik berbasis karakter untuk guru SD yang langsung dari pakar pendidikan ilmu sosial. Ahli Pendidikan Guru Sekolah Dasar Konsentrasi PPKn. Kegiatan pendidikan, pelatihan dan pendampingan yang dilakukan pada guru SD Negeri 104202 di Desa Bandar Setia Kecamatan Percut Sei Tuan Kabupaten Deli Serdang meliputi materi Pendidikan Pancasila dan Kewarganegaraan terkhusus PPKn kelas rendah dan kelas tinggi. Ahli Pendidikan Guru Sekolah Dasar Konsentrasi IPA. Pembuatan pedoman penilaian autentik berbasis karakter untuk guru SD Negeri 104202 di Desa Bandar Setia Kecamatan Percut Sei Tuan Kabupaten Deli Serdang perlu adanya pelatihan dan pendampingan pembuatan penilaian autentik berbasis karakter untuk guru SD. Ahli Pendidikan Guru Sekolah Dasar Konsentrasi PPKn.

Selanjutnya, guru SD yang terlibat pada kegiatan pendampingan penilaian autentik berbasis karakter untuk guru SD Desa Bandar Setia Kecamatan Percut Sei Tuan Kabupaten Deli Serdang meliputi ibu Seriani Nasution, Sri Anita, Suharningsih, Ermiati, Sutresni, Nurhamidah Siregar, Sofia Hasan, Siti Jumaiyah, Neng Dewi Asriani, Tri Novita, Ainun Mardiah, Rizki Ayu Pratiwi Rizki Ayu Pratiwi, Maulida Sari.

\section{SIMPULAN}

Tersedianya Instrumen Penilaian Autentik Berbasis Karakter untuk SD untuk mendukung perangkat pembelajaran dalam penguatan karakter siswa, melalui aktivitas pembelajaran yang dilakukan guru. Adanya pedoman penilaian autentik berbasis 
karakter untuk Sekolah Dasar, dimana Guru sudah dapat melakukan penilaian autentik secara langsung untuk mencapai nilai karakter pada diri siswa. Terbentuknya Kelompok Kerja Guru (KKG) dalam melaksanakan Penilaian Autentik Berbasis Karakter untuk Sekolah Dasar Negeri 104202 di Desa Bandar Setia Kecamatan Percut Sei Tuan Kabupaten Deli Serdang.

\section{DAFTAR PUSTAKA}

Arikunto, S. (2006). Dasar-dasar Evaluasi Pendidikan. Jakarta: Bumi Aksara.

Bhakti, A. S. , dkk.. (2014). Pengembangan Penilaian Autentik Berbasis Kurikulum 2013. Jurnal Forum Penelitian. Vol. 1.

Damanik, F.H.S. (2014). Hakikat Pancasila dalam Membentuk Karakter Kebangsaan melalui Organisasi Siswa Intra Sekolah. Jurnal Pendidikan Ilmu-Ilmu Sosial, 6 (2): 49-60.

Damanik, M Ridha S dan Deny S. (2016), Pengembangan Penilaian Autentik Berbasis Karakter pada Ranah Keterampilan di Fakultas Ilmu Sosial, Universitas Negeri Medan, Jurnal Pendidikan Ilmu-Ilmu Sosial, 8 (2) (2016): 88-94

Dharma, S. dan Rosnah Siregar (2014). Internalisasi Karakter melalui Model Project Citizen pada Pembelajaran Pendidikan Pancasila dan Kewarganegaraan, Jurnal Pendidikan Ilmu-Ilmu Sosial 6 (2) (2014): 132-137

Hariyani, R.S. (2018). Upaya Mewujudkan Pendidikan Karakter Bangsa dalam Proses Kegiatan Belajar Mengajar di Sekolah Menengah Kejuruan Negeri 3 Karang Baru Aceh Tamiang. JUPIIS: Jurnal Pendidikan Ilmu-ilmu Sosial, 11 (1):121-134.

Hosnan. (2014). Pendekatan Saintifik dan konstektual dalam Pembelajaran Abad 21. Jakarta: Ghalia Indonesia.

Kardiman. (2015). Membangun Kembali Karakter Bangsa Melalui Situs Situs Kewarganegaraan, Acta Civicus: Jurnal Pendidikan Kewarganegaraan, Volume 2, Nomor 2. 2015.

Kinay, I., Bagceci, B. (2016). The Investigation of the Effects of Authentic Assessment Approach on Prospective Teachers' Problem-Solving Skills, International Education Studies, Vol. 9 (8).

Komalasari, K. (2013). Pembelajaran Kontekstual: Konsep dan Aplikasi. Bandung: Refika Aditama.

Lickona, T. (2000). Talks about Character Education, wawancara oleh Early Childhood Today. ProQuest Education Journal, April 2000, http://webcache.google.usercontent.com.

Majid. (2014). Pembelajaran Tematik Terpadu. Bandung: Remaja Rosdakarya.

Muslich, M. (2009). Melaksanakan PTK. Jakarta: Bumi Aksara.

Mustika, F. \& Sahudra, T.M. (2018). Peranan Lingkungan Sosial terhadap Pembentukan Karakter Peduli Lingkungan Mahasiswa Pendidikan Geografi di Universitas Samudra Langsa. JUPIIS: Jurnal Pendidikan Ilmu-ilmu Sosial, 10 (2): 235-244.

Najmina, N. (2018). Pendidikan Multikultural Dalam Membentuk Karakter Bangsa Indonesia. Jurnal Pendidikan Ilmu-Ilmu Sosial, 10 (1): 52-56.

Nasution, A.R., (2016), Urgensi Pendidikan Kewarganegaraan sebagai Pendidikan Karakter Bangsa Indonesia melalui Demokrasi, HAM dan Masyarakat Madani, Jurnal Pendidikan Ilmu-Ilmu Sosial, 8 (2) (2016): 201-212.

Newmann, F.M., et.al. (1995). A Guide to Authentic Instruction and Assessment: Vision, Standard, and Scoring. Wisconsin: Wisconsin Center For Educational Research.

Nurgiyantoro, B. (2011). Penilaian Otentik. Yogyakarta: UGM Press.

Rumapea, M.E.M. (2015). Urgensi Pendidikan Karakter d Perguruan Tinggi, Jurnal Pendidikan Ilmu-Ilmu Sosial, 7 (1) (2015): 49-59.

Setiawan, D. (2014). Pendidikan Kewarganegaraan Berbasis Karakter melalui Penerapan Pendekatan Pembelajaran Aktif, Kreatif, Efektif dan Menyenangkan, Jurnal Pendidikan Ilmu-Ilmu Sosial, 6 (2): 6172.

Setiawan, D. (2017), Kontribusi Tingkat Pemahaman Konsepsi Wawasan Nusantara terhadap Sikap Nasionalisme dan Karakter Kebangsaan, Jurnal Pendidikan Ilmu-Ilmu Sosial, 9 (1): 20-27.

Undang-Undang Nomor 20 Tahun 2003 tentang Sistem Pendidikan Nasional 